\title{
Identyfikacja ryzyka \\ w zarządzaniu projektami \\ - praktycy a eksperci
}

\author{
Dr Hanna Soroka-Potrzebna \\ Uniwersytet Szczeciński, Wydział Ekonomii, Finansów i Zarządzania \\ Instytut Zarządzania, Katedra Organizacji i Zarządzania
}

\section{Wprowadzenie}

\begin{abstract}
Współczesna nauka pozbawiła nas złudzeń co do istnienia w'świecie stałych i niezmiennych reguł. Wzrosło natomiast uświadomienie sobie niepewności, niemożliwości i niebezpieczeństwa spoteggowanego zwłaszcza rozwojem techniki. [...] Ryzyko jest wkomponowane $w$ dynamiczny, ewolucyjny model świata i dlatego jest czymś obiektywnym ${ }^{1}$.
\end{abstract}

Otaczająca nas rzeczywistość, która dynamicznie się zmienia, stwarza ogromne szanse rozwoju, ale jednocześnie zwiększa ryzyko podejmowanych decyzji. Projekty, w porównaniu z innymi obszarami działalności przedsiębiorstwa, z uwagi na swą unikatowość oraz niepowtarzalność, wiążą się z wyższym poziomem ryzyka. Ponadto realizacja większości projektów pociąga za sobą wysokie nakłady inwestycyjne, przy braku pełnej wiedzy o przyszłych okresach realizacji projektu. Wszystkie te czynniki wymuszają na przedsiębiorstwach, a przede wszystkim na kierownikach projektów, stosowanie odpowiednich metod rozpoznawania ryzyka w projektach.

W artykule analizowane są wyniki badań przeprowadzonych wśród realizujących projekty podmiotów z województwa zachodniopomorskiego oraz wśród wysokiej klasy praktyków zarządzania projektami, pełniących funkcję asesorów CERT International Project Management Association Polska (IPMA Polska). Celem artykułu jest porównanie etapu identyfikacji ryzyka w procesie zarządzania projektami w praktyce z zaleceniami ekspertów. Do przeprowadzenia badań wykorzystano metodę CAWI, wywiady oraz analizę statystyczną. Wyniki badań pozwolą odpowiedzieć na pytanie, czy etap identyfikacji ryzyka jest ważny, i czy jest

1 W. Szumski, Ryzyko iświadomość ryzyka, [w:] L. Zacher, A. Kiepas (red.), Spoteczeństwo a ryzyko, Fundacja Edukacyjna Transformacja w Warszawie, Warszawa-Katowice 1994, s. 26. 
stosowany przez podmioty realizujące projekty. Ponadto ukażą, jakie metody wykorzystują w tym celu podmioty realizujące projekty, a jakie są zalecane przez specjalistów z zakresu zarządzania projektami.

\section{Proces zarządzania ryzykiem projektowym}

Zarządzanie ryzykiem projektowym polega na identyfikacji zagrożeń dla projektu oraz określeniu działań zmierzających do eliminacji wykrytych zagrożeń lub minimalizacji ich wpływu na projekt ${ }^{2}$. Ma ono fundamentalne znaczenie dla osiągnięcia celów projektu, nie tylko minimalizując złe wyniki, ale także działając jako przewodnik dla maksymalizacji pozytywnych rezultatów ${ }^{3}$.

Proces zarządzania ryzykiem ma sekwencyjny charakter, który powinien być realizowany w sposób ciągły. W ramach procesu wyróżniamy pięć etapów ${ }^{4}$ :

- identyfikacji ryzyka - polegający na określeniu potencjalnych zdarzeń, które mogą negatywnie lub pozytywnie wpłynąć na realizację projektu; wystąpienie określonego zdarzenia zależy od wielu czynników, stąd powinno się uwzględnić mieszaninę czynników środowiskowych, programowych i sytuacyjnych;

- jakościowej analizy ryzyka - procesu priorytetyzacji czynników ryzyka, realizowanego przez ocenę, a także odniesienie prawdopodobieństwa wystąpienia czynników ryzyka do ich skutków;

- ilościowej analizy ryzyka - procesu analizy wpływu zidentyfikowanych czynników ryzyka na ogólne cele projektu;

- sterowania ryzykiem - polegającego na opracowaniu dopuszczalnych rozwiązań oraz działań, które mają na celu maksymalizację szans i minimalizację zagrożeń projektu;

- kontroli ryzyka - procesu polegającego na wdrożeniu planów reakcji na ryzyko, monitorowaniu zidentyfikowanego ryzyka oraz rozpoznawaniu nowego ryzyka.

2 P. Zaskórski i wsp., Zarzq̨dzanie projektami w ujęciu systemowym, Wojskowa Akademia Techniczna, Warszawa 2013, s. 31.

3 J. Górecki, Big Data as a Project Risk Management Tool, Risk Management Treatise for Engineering Practitioners, 2018, https://www.intechopen.com/books/risk-management-trea tise-for-engineering-practitioners/big-data-as-a-project-risk-management-tool (dostęp: 3.01.2020).

4 C.L. Pritchard, Zarządzanie ryzykiem w projektach. Teoria i praktyka, WIG Press, Warszawa 2002, s. 23-26; PMI, A Guide to the Project Management Body of Knowledge, PMBOK ${ }^{\circledR}$, Pennsylvania 2013, s. 301-304; M. Wirkus i wsp., Zarzqqdzanie projektem, Polskie Wydawnictwo Ekonomiczne, Warszawa 2014, s. 201-203. 


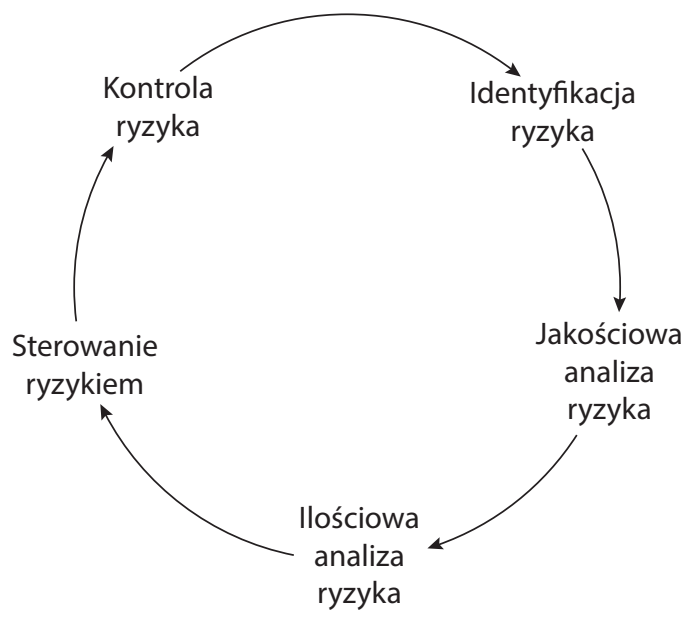

Rysunek 1. Proces zarządzania ryzykiem w projekcie

Źródto: opracowanie własne na podstawie PMI, A Guide to the Project Management Body of Knowledge, PMBOK ${ }^{\oplus}$, Pennsylvania 2013, s. 301-304.

Identyfikacja ryzyka jest pierwszym etapem procesu zarządzania ryzykiem, który polega na wyszczególnieniu potencjalnych zagrożeń lub szans. Etap ten umożliwia rozpoznanie tych zdarzeń, które mogą mieć wpływ na osiągnięcie zamierzonego celu projektu 5 .

Metodyki zarządzania projektami prezentują wiele różnych metod, które służą do gromadzenia i wykorzystania informacji w zakresie rozpoznawania ryzyka. Metodyki tradycyjne wyróżniają między innymi: burzę mózgów, metodę delficką, analizę przyczyn źródłowych, analizę list kontrolnych, analizę SWOT ${ }^{6}$. Zwinne metodyki zarządzania projektami najczęściej opisują: przeglądy rejestrów ryzyka, warsztaty facylitowane czy też Bug Trackery?

W literaturze przedmiotu wymienianych i opisywanych jest wiele różnych metod, z których mogą korzystać zespoły projektowe. Różnią się one łatwością wykorzystania, wymaganiami infrastruktury i wyposażenia, użytecznością i dokładnością otrzymanych danych, stopniem niepewności otrzymanej oceny. Nie zawsze jednak teoria pokrywa się z praktyką. Stąd pojawia się pytanie, z których metod najczęściej korzystają kierownicy projektu, a które są zalecane przez specjalistów.

5 M. Klinowski, Ryzyko w analizie i ocenie projektów, „Prace Naukowe Uniwersytetu Ekonomicznego we Wroctawiu” 2014, nr 344, s. 230-244.

6 PMI, A Guide..., s. 301.

7 DSDM Consortium, Agile PM - Agile Project Management Handbook v. 1.2, 2010, s. 177-184. 


\section{Identyfikacja ryzyka - badania wśród podmiotów z województwa zachodniopomorskiego}

W okresie od października do grudnia 2019 roku przeprowadzono badanie wśród podmiotów, które zrealizowały lub realizują projekty i znajdują się w bazie Urzędu Marszałkowskiego Województwa Zachodniopomorskiego. Badanie przeprowadzone zostało przy użyciu metody CAWI (Computer-Assisted Web Interview), a w jego wyniku uzyskano sto pięćdziesiąt dwie odpowiedzi. Ankietowanym zadano dwadzieścia cztery pytania, w tym sześć pytań metryczkowych. Do analizy otrzymanych wyników wykorzystano metodę statystyczną, do wykonania której użyto oprogramowania MS Excel 2016.

Próba badawcza obejmowała w największym stopniu instytucje publiczne i jednostki samorządu terytorialnego (43,2\%), średnie przedsiębiorstwa (17,6\%), oraz mikro- i małe przedsiębiorstwa (25,7\%). Dokładny podział grupy badawczej według typów podmiotów prezentuje rysunek 2 . Podmioty reprezentowały różne branże, między innymi: oświatę i wychowanie $(27,6 \%)$, przemysł $(18,4 \%)$, ochronę zdrowia i opiekę zdrowotną (10,5\%), budownictwo (7,9\%), kulturę fizyczną, turystykę i wypoczynek (7,9\%). Wśród podmiotów dominowały małe zespoły projektowe, składające się maksymalnie z trzech osób $(39,5 \%)$ oraz zespoły czteroosobowe $(15,8 \%)$.

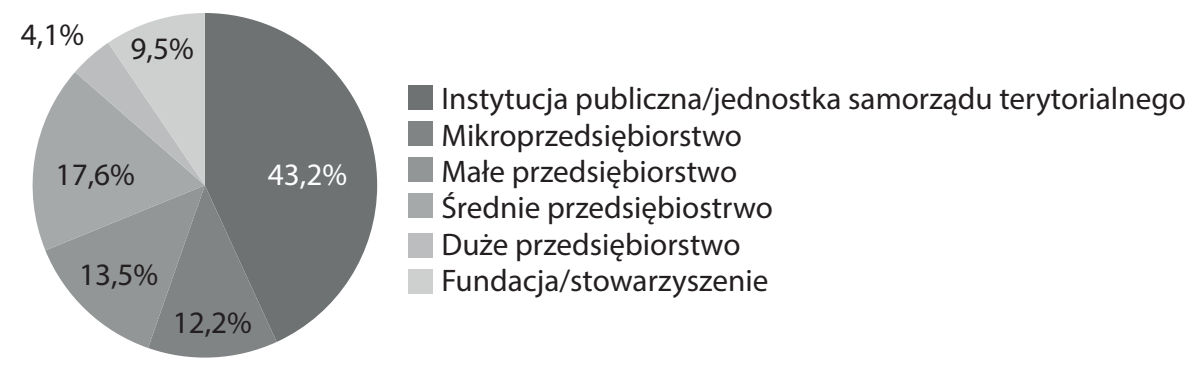

Rysunek 2. Podział próby badawczej wedtug typów podmiotów

Źródło: badanie własne.

Projekty realizowane przez badane podmioty w przeważającej większości trwały mniej niż 2 lata ( $82 \%$ badanych), w tym projekty do roku stanowiły ich połowę (41\% badanych). Budżety analizowanych projektów były bardzo zróżnicowane pod względem wielkości: budżety poniżej 500 tys. zł stanowiły 22\% analizowanych projektów, między 500 tys. a $1 \mathrm{mln}$ zł - 20\% projektów, 1-2 mln zł - 17\% projektów, 2-5 mln zł - 26\% projektów, a reszta stanowiła projekty o budżecie powyżej 
$5 \mathrm{mln}$ zł. Środki na realizację projektów w większości pochodziły z dotacji unijnych (88\%), pozostałe zaś z kredytów, grantów lub środków własnych.

Na pytanie o pojęcie ryzyka aż $67 \%$ ankietowanych podmiotów odpowiedziało, że jest to tylko możliwość zaistnienia negatywnych zdarzeń, tylko 33\% dostrzegało w ryzyku również możliwość zdarzeń pozytywnych. Mimo iż 100\% ankietowanych widziało w ryzyku możliwość straty, tylko 87\% dokonało identyfikacji ryzyka przed rozpoczęciem realizacji projektu. Identyfikacja ryzyka dotyczyła przede wszystkim ryzyka zachowania ram czasowych (30\%), ryzyka finansowego (27\%), ryzyka dotyczącego planowanych rozwiązań technicznych i technologicznych (19\%) oraz ryzyka prawnego (12\%).

Ankietowanym podmiotom zadano pytanie o metodę identyfikacji ryzyka, którą wykorzystywały w swoich projektach. Najczęściej wymienianymi metodami były burza mózgów oraz przegląd dokumentacji, nieco rzadziej analiza SWOT oraz listy kontrolne. Najrzadziej wśród odpowiedzi pojawiały się: specjalistyczne oprogramowanie, technika kuli śniegowej, kwiat lotosu oraz metoda morfologiczna. Pojedyncze osoby wskazywały również na obserwację zmian makroekonomicznych i ustawodawczych, przegląd rynku i jego analizę, bieżący monitoring. Analiza odpowiedzi według typów badanych podmiotów pokazuje, że najbardziej różnorodne metody wykorzystują przedsiębiorstwa. Procentowy udział odpowiedzi ogółem oraz według typów podmiotów prezentuje tabela 1.

Tabela 1. Metody identyfikacji ryzyka stosowane przez badane podmioty (w \%)

\begin{tabular}{|l|c|c|c|c|}
\hline \multirow{2}{*}{$\begin{array}{c}\text { Metoda identyfikacji } \\
\text { ryzyka }\end{array}$} & \multicolumn{4}{|c|}{ Procent udzielonych odpowiedzi } \\
\cline { 2 - 5 } & Ogótem & $\begin{array}{c}\text { Instytucje pub- } \\
\text { liczne/JST }\end{array}$ & Przedsiębiorstwa & $\begin{array}{c}\text { Fundacje/sto- } \\
\text { warzyszenia }\end{array}$ \\
\hline Burza mózgów & 43,6 & 59 & 71 & 50 \\
\hline Przegląd dokumentacji & 42,3 & 69 & 57 & 0 \\
\hline Analiza SWOT & 27,9 & 31 & 43 & 100 \\
\hline Lista kontrolna & 20,9 & 28 & 29 & 0 \\
\hline Dyskusja 66 & 7,3 & 6 & 9 & 0 \\
\hline Analiza portfelowa & 7,3 & 6 & 11 & 0 \\
\hline Synektyka & 2,7 & 6 & 3 & 0 \\
\hline $\begin{array}{l}\text { Specjalistyczne } \\
\text { oprogramowanie }\end{array}$ & 1,8 & 0 & 6 & 0 \\
\hline Kwiat lotosu & 1,8 & 0 & 3 & 0 \\
\hline Metoda morfologiczna & 1,8 & 0 & 6 & 0 \\
\hline Technika kuli śniegowej & 0,9 & 0 & 3 & 0 \\
\hline Inne & 5,4 & 3 & 4 & \\
\hline
\end{tabular}

Źródło: badania własne.

Wybór wskazywanych metod identyfikacji ryzyka ankietowani motywowali przede wszystkim ich skutecznością (38\%), łatwością w realizacji (36\%) oraz niskim 
kosztem (17\%). Na pytanie o zaistnienie zidentyfikowanego ryzyka w trakcie realizacji projektu aż $62 \%$ badanych odpowiedziało, że ryzyko zaistniało. Tylko $17 \%$ ankietowanych przyznało, że pojawiło się ryzyko, którego nie zidentyfikowali przed rozpoczęciem realizacji projektu. Wśród niezidentyfikowanych rodzajów ryzyka pojawiły się między innymi: czynnik ludzki, wzrost cen, złe warunki atmosferyczne, decyzje polityczne.

Ostatecznie 76\% badanych podmiotów przyznało, że projekt zakończył się sukcesem, $3 \%$ było jeszcze w trakcie realizacji, a $21 \%$ projektów zakończyło się z odchyleniami dotyczącymi terminu, budżetu lub zakresu prac projektowych. Prawie wszyscy badani (93\%) przyznali, że etap identyfikacji ryzyka jest istotnym punktem przed rozpoczęciem realizacji projektu, a co za tym idzie - wybór właściwych metod jest bardzo ważny dla powodzenia projektu.

\section{Identyfikacja ryzyka - wyniki badań wśród asesorów CERT IPMA Polska}

W listopadzie 2019 roku przeprowadzono wywiady wśród asesorów certyfikacji International Project Management Association Polska, którzy zajmują się oceną kompetencji kierowników projektów, między innymi w zakresie zarządzania ryzykiem projektowym. Wywiady przeprowadzone zostały z pięcioma z czternastu asesorów CERT IPMA Polska. Wszyscy badani posiadają certyfikaty IPMA B oraz wieloletnie doświadczenie w prowadzeniu projektów jako kierownicy projektów. Doświadczenie badanych ekspertów w pełnieniu funkcji asesora CERT IPMA Polska wynosi od trzech do dziesięciu lat.

Badani jednogłośnie określili ryzyko jako możliwość zaistnienia negatywnych lub pozytywnych zdarzeń, którego identyfikacja stanowi jeden z kilku najważniejszych elementów obszaru zarządzania projektem. Na pytanie, które grupy ryzyka powinny być identyfikowane przed realizacją projektu, asesorzy podawali różne odpowiedzi, między innymi: ryzyko finansowe, ryzyko prawne, ryzyko dotyczące planowanych rozwiązań technicznych i technologicznych oraz ryzyko związane z wymogami BHP. Jednak jednomyślnie przyznali, że poziom analiz ryzyka powinien być zgodny z budżetem, czasem i zakresem przewidzianym na działania poprzedzające projekt.

Wśród metod zalecanych przez asesorów do identyfikacji ryzyka w projekcie wymieniane były przede wszystkim: listy kontrolne (4 odpowiedzi), burza mózgów (3 odpowiedzi), metoda morfologiczna (3 odpowiedzi), analiza SWOT (3 odpowiedzi) oraz specjalistyczne oprogramowanie (2 odpowiedzi). Asesorzy podkreślali przy tym, że identyfikacja ryzyka powinna być pracą zespołową nadzorowaną 
przez kierownika projektu. Na pytanie o najlepszą metodę żaden z asesorów nie udzielił jednoznacznej odpowiedzi. Jeden $z$ asesorów stwierdził, że nie może wskazać tylko jednej metody, $z$ uwagi na fakt, iż jest ona każdorazowo dobierana do zaistniałego problemu lub zagadnienia. Inny asesor powiedział zaś, że wszystkie opisywane w literaturze metody są mało skuteczne przy poszukiwaniu wtórnych lub ukrytych grup ryzyka.

Wszyscy badani asesorzy podkreślali, że etap identyfikacji ryzyka jest istotnym punktem przed rozpoczęciem realizacji projektu, a wybór odpowiedniej metody pomaga uniknąć negatywnych zdarzeń lub wspomóc pozytywne zdarzenia w trakcie realizacji projektu.

\section{Porównanie wyników badań dotyczących identyfikacji ryzyka w projektach}

Porównanie uzyskanych wyników badań pozwoliło ukazać, że definicja ryzyka inaczej pojmowana jest przez ekspertów niż przez większość podmiotów realizujących projekty. Aż dwie trzecie ankietowanych nie identyfikowało ryzyka z możliwością zaistnienia pozytywnych zdarzeń, a jedynie z możliwością poniesienia straty. Mogło to wynikać z faktu, iż traktowanie ryzyka jako szansy lub zagrożenia powoduje konieczność korzystania ze zdecydowanie bardziej skomplikowanych narzędzi i metod. Tym samym kierownicy projektów, zawężając pojęcie ryzyka do zagrożeń, ułatwiają zarządzanie projektem.

Mimo iż według specjalistów identyfikacja ryzyka to jeden z kluczowych elementów zarządzania projektem, nie jest ona dokonywana przez wszystkie zespoły projektowe. Aż 13\% kierowników projektów przyznało, że nie przeprowadziło identyfikacji ryzyka przed rozpoczęciem realizacji projektu. Z tych, którzy tego dokonali, najwięcej podkreślało znaczenie ryzyka zachowania ram czasowych, ryzyka finansowego, ryzyka dotyczącego planowanych rozwiązań technicznych i technologicznych oraz ryzyka prawnego. Wymieniane grupy ryzyka były w większości zgodne ze wskazanymi przez asesorów.

Asesorzy wskazali na pięć najważniejszych ich zdaniem metod identyfikacji ryzyka w projektach: listy kontrolne, burzę mózgów, metodę morfologiczną, analizę SWOT oraz specjalistyczne oprogramowanie. Z odpowiedzi jasno wynika, że nie można wskazać jednej najlepszej metody, gdyż jest to zależne od projektu. Odpowiedzi podmiotów częściowo pokrywały się z udzielonymi przez asesorów - wykorzystywali oni również burzę mózgów, analizę SWOT oraz listy kontrolne, a pozostałe metody wskazane przez asesorów zdecydowanie rzadziej. Wykorzystywane metody oraz ich liczba różniły się również w zależności od typu podmiotu. 
Zdecydowanie najwięcej rodzajów metod wskazały przedsiębiorstwa, których odpowiedzi były najbliższe tym udzielanym przez asesorów. Najmniej zgodne były zaś odpowiedzi udzielone przez fundacje.

Wszyscy asesorzy i prawie wszystkie badane podmioty przyznali, że etap identyfikacji ryzyka jest istotnym punktem przed rozpoczęciem realizacji projektu, co wskazuje na ogromne znaczenie właściwego wyboru metod do jej przeprowadzenia.

\section{Podsumowanie}

Niepewność oraz złożoność projektu wpływają na ryzyko realizacji całego przedsięwzięcia. Ryzyko rozumiane jako możliwość poniesienia straty dostrzegały wszystkie badane podmioty. Jednak drugą stronę ryzyka, jaką jest możliwość pozytywnych zdarzeń, zauważyły już tylko dwa na trzy badane podmioty. Choć zarządzanie ryzykiem w projekcie, pojmując ryzyko zarówno jako szansę, jak i zagrożenie, jest o wiele trudniejszym zadaniem, to specjaliści zgodnie potwierdzili, że właśnie takie podejście do ryzyka jest właściwe. Istotne w tym zakresie jest pokazanie podmiotom realizującym projekty ryzyka jako możliwości osiągnięcia korzyści. Przydatne mogą być tu doradztwa, konsultacje, ale także organizowanie spotkań, na których prezentowane byłyby przykłady ryzyka jako pozytywnych zdarzeń dla realizacji projektu.

Pierwszy etap procesu zarządzania ryzykiem projektowym, jakim jest jego identyfikacja, jest niezwykle ważny dla sukcesu projektu. Wyniki badań omówione w niniejszym artykule potwierdziły, że jest to jeden z najważniejszych elementów zarządzania projektem, co przyznały zarówno podmioty realizujące projekty, jak i specjaliści z zakresu zarządzania projektami. Obie grupy wśród najważniejsze rodzajów ryzyka, które należy identyfikować przed realizacją projektu, wymieniły ryzyko: finansowe, dotyczące planowanych rozwiązań technicznych i technologicznych oraz prawne.

W literaturze przedmiotu wymienianych jest wiele różnych metod identyfikacji ryzyka, co z jednej strony potwierdza istotę tego etapu, z drugiej zaś daje wybór osobom zarządzającym projektem. Porównanie uzyskanych wyników badań z obu grup badawczych pokazuje, że istnieją mniej i bardziej popularne metody, które wykorzystują zespoły projektowe. Zróżnicowanie wynika przede wszystkim ze skuteczności tych metod, łatwości realizacji, ale również kosztu ich wdrożenia. Nie wszystkie metody są dostępne dla każdego kierownika projektu. Niektóre wymagają specjalistycznej wiedzy z zakresu stosowanej metody, a także określonej infrastruktury lub wyposażenia. Analiza porównawcza wyników badań ukazała jednak, że metody rekomendowane przez specjalistów pokrywają się częściowo 
z tymi wykorzystywanymi w praktyce. Najbardziej zgodne były odpowiedzi przedsiębiorców, mniej instytucji publicznych i jednostek samorządowych, a najmniej fundacji. Może to wynikać z przyjętych zasad i procedur działania podmiotów, które są zdecydowanie bardziej restrykcyjne i narzucone odgórnie w przypadku podmiotów publicznych.

Ograniczeniem przeprowadzonych analiz jest zawężenie grupy badawczej tylko do województwa zachodniopomorskiego oraz specjalistów z IPMA Polska. Badania stanowią jednak wstęp do dalszej analizy tematyki zarządzania ryzykiem w projektach, która zostanie rozszerzona o monitorowanie ryzyka w trakcie realizacji projektu i obejmie podmioty działające na terenie całego kraju.

\section{Bibliografia}

DSDM Consortium, Agile PM - Agile Project Management Handbook v. 1.2, 2010.

Górecki J., Big Data as a Project Risk Management Tool, Risk Management Treatise for Engineering Practitioners, 2018, https://www.intechopen.com/books/risk-management-treatise-for-en gineering-practitioners/big-data-as-a-project-risk-management-tool (dostęp: 3.01.2020).

Klinowski M., Ryzyko w analizie i ocenie projektów, „Prace Naukowe Uniwersytetu Ekonomicznego we Wroctawiu" 2014, nr 344, s. 230-244.

PMI, A Guide to the Project Management Body of Knowledge, PMBOK ${ }^{\circledR}$, Pennsylvania 2013.

Pritchard C.L., Zarzq̨dzanie ryzykiem w projektach. Teoria i praktyka, WIG Press, Warszawa 2002. Szumski W., Ryzyko i świadomość ryzyka, [w:] L. Zacher, A. Kiepas (red.), Społeczeństwo a ryzyko, Fundacja Edukacyjna Transformacja w Warszawie, Warszawa-Katowice 1994.

Wirkus M., Roszkowski H., Dostatni E., Gierulski W., Zarzq̨dzanie projektem, Polskie Wydawnictwo Ekonomiczne, Warszawa 2014.

Zaskórski P., Woźniak J., Szwarc K., Tomaszewski Ł., Zarzq̨dzanie projektami w ujęciu systemowym, Wojskowa Akademia Techniczna, Warszawa 2013.

\section{Streszczenie}

Każdy projekt z założenia obarczony jest pewnym ryzykiem. Można je ograniczyć lub wykorzystać, ale niezbędne do tego jest jego zidentyfikowanie. W literaturze przedmiotu opisanych jest wiele metod identyfikacji ryzyka, które różnią się specyfiką wykorzystania. Artykuł ma na celu porównanie etapu identyfikacji ryzyka w procesie zarządzania projektami stosowanej przez zespoły projektowe z zaleceniami asesorów IPMA Polska. W tym celu wykorzystano analizę przeprowadzonych badań ankietowych oraz wywiadów.

Wyniki przeprowadzonych badań pozwoliły ukazać, jak pojmowane jest ryzyko, na jakie ryzyka zwracana jest szczególna uwaga, czy identyfikacja ryzyka przed rozpoczęciem realizacji projektu jest istotna i jakie metody są w tym celu wykorzystywane oraz zalecane.

Słowa kluczowe: ryzyko, zarządzanie, projekt, metoda, identyfikacja, analiza 
Identification of risk in project management - practitioners and experts

\section{Abstract}

Each project is assumed to carry some risk. Risk can be limited or used, but it is necessary to identify it. The literature on the subject describes many risk identification methods that differ in the specificity of use. The article aims to compare the risk identification process used by project teams with the recommendations of CERT IPMA Polska assessors. For this purpose, an analysis of surveys and interviews was used.

The results of the research allowed to show how the risk is perceived, to which risks particular attention is paid, whether the identification of risk before the start of the project is important and what methods are used and recommended for this purpose.

Keywords: risk, management, project, method, identification, analysis 